\title{
HUBUNGAN JUMLAH TROMBOSIT DAN JUMLAH LEUKOSIT PADA PASIEN ANAK DEMAM BERDARAH DENGUE
}

\author{
Jilly J.G Masihor \\ Max F.J Mantik \\ Maya Memah \\ Arthur E. Mongan

\begin{abstract}
Bagian Patologi Klinik Fakultas Kedokteran Universitas Sam Ratulangi Manado Email: jillymasihor09054@yahoo.com
\end{abstract}

\begin{abstract}
Dengue hemorrhagic fever is an acute fever disease with high mortality and morbidity in many regions of the world. Leucopenia and thrombocytopenia are two of several laboratory findings that could be found in the course of dengue hemorrhagic fever. An analytical retrospective research with cross sectional approach. Samples are patients that diagnosed with dengue hemorrhagic fever in RSUP Prof. Dr. R.D Kandou Manado during the period of 2012. Patients were included in the inclusion criteria were patients $<15$ years old and have been diagnosed according to WHO 1997 criteria, and laboratory examination of platelets and white blood cells count. This research used medical record and for the statistical analysis used Pearson's correlation test. There were 137 children with dengue hemorrhagic fever during the period of 2012 and 56 children were sampled in this research. Conclusion: It was found that there was no significant relationship between the number of thrombocytes and leukocytes in children with dengue hemorrhagic fever $(\mathrm{p}=0.801)$.
\end{abstract}

Keywords: dengue hemorrhagic fever, leukocyte, thrombocyte

\begin{abstract}
Abstrak: Demam berdarah dengue merupakan penyakit demam akut dengan morbiditas dan mortalitas yang tinggi di banyak daerah di dunia. Leukopenia dan trombositopenia merupakan dua temuan laboratorium yang sering ditemukan pada perjalanan penyakit DBD. Penelitian ini bersifat analitik retrospektif dengan pendekatan potong lintang. Sampel penelitian adalah pasien anak yang terdiagnosis DBD di RSUP Prof. Dr. R.D. Kandou Manado selama periode tahun 2012. Pasien yang masuk dalam kriteria inklusi adalah pasien $<15$ tahun dan telah terdiagnosis menurut kriteria WHO 1997, serta melakukan pemeriksaan laboratorium trombosit dan leukosit. Penelitian ini menggunakan catatan rekam medik, dan untuk analisis statistik digunakan pearson's correlation test. Terdapat 137 anak dengan demam berdarah dengue pada periode 2012 dan 56 anak menjadi sampel dalam penelitian ini. Simpulan: Didapatkan bahwa tidak terdapat hubungan yang signifikan antara jumlah trombosit dan leukosit pada pasien anak demam berdarah dengue $(\mathrm{p}=0,801)$.
\end{abstract}

Kata Kunci: demam berdarah dengue, leukosit, trombosit

Demam berdarah dengue banyak ditemukan di daerah tropis dan sub-tropis. Data dari seluruh dunia menunjukkan Asia menempati urutan pertama dalam jumlah penderita DBD setiap tahunnya. Sementara itu, terhitung sejak tahun 1968 hingga tahun 2009, World Health Organization (WHO) mencatat negara Indonesia sebagai negara dengan kasus DBD tertinggi di Asia Tenggara. Di Indonesia DBD telah menjadi masalah kesehatan masyarakat selama 41 tahun terakhir. ${ }^{1}$

Di Sulawesi Utara dari 15 kabupaten/kota, jumlah kabupaten/kota yang terjangkit demam berdarah dengue sebanyak 9 kab/kota (60,00\%) tahun 2008, 
11 kab/kota (73,33\%) tahun 2009, 12 kab/kota $(80,00 \%)$ tahun 2010, dan 8 kab/kota (53,33\%) tahun 2011. Total jumlah penduduk di Sulawesi Utara pada tahun 2011 adalah 2.298.489 penduduk, dengan jumlah kasus yang terinfeksi DBD sebanyak 364 kasus, dan total kasus yang meninggal adalah 5 kasus dengan Case Fatality Rate 1,37\% dan Incidence Rate 15,84 per 100.000 penduduk. $^{2}$

Trombosit dihasilkan dalam sumsum tulang melalui fragmentasi sitoplasma megakariosit. Jumlah trombosit normal adalah sekitar $250 \times 10^{9} /$ (rentang 150 $400 \times 10^{9} /$ ) dan lama hidup trombosit yang normal adalah 7 - 10 hari. Fungsi utama trombosit adalah pembentukan sumbat mekanik selama respons hemostasis normal terhadap cedera vaskular. Tanpa trombosit, dapat terjadi kebocoran darah spontan melalui pembuluh darah kecil. ${ }^{3}$

Penurunan jumlah trombosit $<150.000 / \mu \mathrm{l}$ dikategorikan sebagai trombositopenia. Trombositopenia pada infeksi dengue terjadi melalui mekanisme supresi sumsum tulang, destruksi dan pemendekan masa hidup trombosit. Penyebab trombositopenia pada DBD adalah akibat terbentuknya kompleks virus antibodi yang merangsang terjadinya agregasi trombosit. Agregat tersebut melewati RES sehingga dihancurkan. Peningkatan destruksi trombosit di perifer juga merupakan penyebab trombositopenia pada DBD. ${ }^{4}$

Pada penderita DBD dapat terjadi leukopenia ringan sampai leukositosis sedang. Leukopenia dapat terjadi pada hari demam pertama dan ke-3 pada 50\% kasus DBD ringan. Hal ini sebagian besar disebabkan oleh adanya degenerasi sel PMN yang matur dan pembentukan sel PMN muda. ${ }^{5}$ Pada saat demam, mulai terjadi pengurangan jumlah leukosit dan netrofil disertai limfositosis relatif. Leukopenia mencapai puncaknya sesaat sebelum demam turun dan normal kembali pada 2-3 hari setelah defervescence (demam turun). Penurunan trombosit umumnya mengikuti turunnya leukosit dan mencapai puncaknya bersamaan dengan turunnya demam. ${ }^{6}$
Berdasarkan uraian latar belakang di atas, maka penelitian ini bertujuan untuk mengetahui apakah terdapat hubungan antara jumlah trombosit dan leukosit pada pasien anak dengan DBD di RSUP Prof. Dr. R.D Kandou Manado.

\section{METODOLOGI}

Penelitian ini menggunakan metode penelitian bersifat cross sectional analitik dengan pendekatan retrospektif. Data yang digunakan merupakan data sekunder dari catatan medik penderita demam berdarah dengue periode tahun 2012. Penelitian dilaksanakan di RSUP Prof. Dr. R.D Kandou Manado. Pemeriksaan jumlah trombosit dan leukosit dilakukan dilakukan di laboratorium RSUP Prof. Dr. R.D Kandou Manado.

Subjek penelitian merupakan pasien yang terdiagnosa DBD menurut kriteria WHO 1997 dengan usia < 15 tahun, serta melakukan pemeriksaan laboratorium jumlah trombosit dan leukosit selama periode tahun 2012. Yang termasuk kriteria klinis yaitu demam tinggi mendadak, perdarahan termasuk uji bending positif, petekia, epistaksis, hematemesis, hepatomegali, syok yang ditandai nadi kecil dan cepat dengan tekanan nadi $<20$ $\mathrm{mmHg}$, atau hipotensi disertai gelisah dan akral dingin. Yang termasuk kriteria laboratoris adalah trombositopeniæ ( 100.000/ $\mu \mathrm{L}$ ), hemokonsentrasi (kadar hematokrit $\geq 20 \%$ dari normal). Dua gejala klinis pertama ditambah 2 gejala laboratoris dianggap cukup untuk menegakkan diagnosis kerja DBD.

Data yang terkumpul kemudian dianalisis menggunakan program SPSS 18 for windows. Pearson's correlation test digunakan untuk mengetahui apakah terdapat hubungan antara jumlah trombosit dan jumlah leukosit.

\section{HASIL PENELITIAN}

Terdapat 137 anak dengan demam berdarah dengue pada periode tahun 2012 dan 56 anak menjadi sampel penelitian 
yang memenuhi kriteria inklusi dan eksklusi. Sebanyak 19 anak (33,9\%) dengan DBD pada kelompok usia $1-4$ tahun, dan 37 anak (66,1\%) pada kelompok usia 5-14 tahun (Tabel 1).

Pada Tabel 2 didapatkan 50 orang anak $(89,3 \%)$ dengan trombositopenia, 6 orang anak (10,7\%) dengan jumlah trombosit normal, dan tidak ada yang mengalami trombositosis. Pada Tabel 3 dapat dilihat bahwa dari 56 sampel penelitian, terdapat rata-rata jumlah trombosit adalah $11,1017 / \mathrm{mm}^{3}$, dengan nilai tertinggi $12,44 / \mathrm{mm}^{3}$, nilai terendah $8,70 / \mathrm{mm}^{3}$, dan simpangan baku $0,69582 / \mathrm{mm}^{3}$.

Pada Tabel 4 didapatkan 15 orang anak (26,8\%) dengan leukopenia, 33 orang anak (58,9\%) dengan jumlah leukosit normal, dan 8 orang anak (14,3\%) dengan leukositosis. Pada Tabel 5 dapat dilihat bahwa, dari 56 sampel penelitian terdapat rata-rata nilai jumlah leukosit sebesar $8,6502 / \mathrm{mm}^{3}$, dengan nilai tertinggi $9,90 / \mathrm{mm}^{3}$, nilai terendah $7,65 / \mathrm{mm}^{3}$, dan simpangan baku sebesar $0,51433 / \mathrm{mm}^{3}$.

Tabel 1. Distribusi Penderita Demam Berdarah Dengue Berdasarkan Usia

\begin{tabular}{ccc}
\hline Kelompok usia & $\begin{array}{c}\text { Frekuensi } \\
\text { (orang) }\end{array}$ & $\begin{array}{c}\text { Persen } \\
\text { (\%) }\end{array}$ \\
\hline $\begin{array}{c}\text { Kelompok usia } \\
<1 \text { tahun }\end{array}$ & 0 & 0 \\
$\begin{array}{c}\text { Kelompok usia } \\
\text { 1-4 tahun }\end{array}$ & 19 & 33,9 \\
$\begin{array}{c}\text { Kelompok usia } \\
\text { 5-14 tahun }\end{array}$ & 37 & 66,1 \\
$\quad$ Total & 56 & 100 \\
\hline
\end{tabular}

Hasil uji Pearson terhadap korelasi jumlah trombosit dan leukosit menunjukkan nilai $\mathrm{p}=0,801$ yang berarti bahwa nilai $P \geq 0,05$ nilai alpha. Oleh karena itu dapat disimpulkan bahwa tidak terdapat hubungan yang signifikan antara jumlah trombosit dan jumlah leukosit pada pasien anak dengan DBD di RSUP Prof. Dr. R.D Kandou Manado.
Tabel 2. Frekuensi Jumlah Trombosit

\begin{tabular}{ccc}
\hline $\begin{array}{c}\text { Jumlah } \\
\text { Trombosit } \\
\left(/ \mathbf{m m}^{3}\right)\end{array}$ & Jumlah & \% \\
\hline $\begin{array}{c}\text { Trombositopenia } \\
\left(<150.000 / \mathrm{mm}^{3}\right)\end{array}$ & 50 & 89,3 \\
$\begin{array}{c}\text { Normal } \\
\left(150.000 / \mathrm{mm}^{3}-\right.\end{array}$ & 6 & 10,7 \\
$\left.450.000 / \mathrm{mm}^{3}\right)$ & & \\
Trombositosis \\
$\left(>450.000 / \mathrm{mm}^{3}\right)$ & 0 & 0 \\
Total & 56 & 100 \\
\hline
\end{tabular}

Tabel 3. Nilai Trombosit

\begin{tabular}{ccccc}
\hline $\begin{array}{c}\text { Jumlah } \\
\text { Sampel }\end{array}$ & $\begin{array}{c}\text { Rata-rata } \\
\left(/ \mathbf{m m}^{3)}\right.\end{array}$ & $\begin{array}{c}\text { Nilai } \\
\text { Tertinggi } \\
\left(/ \mathbf{m m}^{3}\right)\end{array}$ & $\begin{array}{c}\text { Nilai } \\
\text { Terendah } \\
\left(\mathbf{m m}^{3}\right)\end{array}$ & $\begin{array}{c}\text { Simpangan } \\
\text { Baku } \\
\left(/ \mathbf{m m}^{3}\right)\end{array}$ \\
\hline 56 & 11,1017 & 12,44 & 8,70 & 0,69582 \\
\hline
\end{tabular}

Tabel 4. Frekuensi Jumlah Leukosit

\begin{tabular}{ccc}
\hline $\begin{array}{c}\text { Jumlah } \\
\text { Leukosit } \\
\left(/ \mathbf{m m}^{3}\right)\end{array}$ & Jumlah & \% \\
\hline $\begin{array}{c}\text { Leukopenia } \\
\left(<4000 / \mathrm{mm}^{3}\right) \\
\text { Normal }\end{array}$ & 15 & 26,8 \\
$\left(\begin{array}{c}\left(4000 / \mathrm{mm}^{3}-\right. \\
\left.10000 / \mathrm{mm}^{3}\right)\end{array}\right.$ & 33 & 58,9 \\
$\begin{array}{c}\text { Leukositosis } \\
\left(>10000 / \mathrm{mm}^{3}\right)\end{array}$ & 8 & 14,3 \\
Total & 56 & 100 \\
\hline
\end{tabular}

Tabel 5. Nilai Leukosit

\begin{tabular}{ccccc}
\hline Jumlah & $\begin{array}{c}\text { Rata- } \\
\text { rata } \\
\left(/ \mathbf{m m}^{3}\right)\end{array}$ & $\begin{array}{c}\text { Nilai } \\
\text { Tertinggi } \\
\left(/ \mathbf{m m}^{3}\right)\end{array}$ & $\begin{array}{c}\text { Nilai } \\
\text { Terendah } \\
\left(/ \mathbf{m m}^{3}\right)\end{array}$ & $\begin{array}{c}\text { Simpangan } \\
\text { baku } \\
\left(/ \mathbf{m m}^{3}\right)\end{array}$ \\
\hline $\mathbf{5 6}$ & 8,6502 & 9.90 & 7.65 & 0,51433 \\
\hline
\end{tabular}




\section{PEMBAHASAN}

Trombositopenia memiliki peran yang penting dalam patogenesis infeksi dengue. Jumlah trombosit pada pasien infeksi dengue mengalami penurunan pada hari ke tiga sampai hari ke tujuh dan mencapai normal kembali pada hari ke delapan atau sembilan. Trombositopenia pada infeksi dengue terjadi melalui mekanisme supresi sumsum tulang, destruksi trombosit dan pemendekan masa hidup trombosit. ${ }^{7}$

Data pada Tabel 2 menunjukkan bahwa dari 56 sampel penelitian, 50 anak (89,3\%) mengalami trombositopenia, 6 anak dengan jumlah trombosit normal, dan tidak terdapat anak dengan trombositosis. Hal ini sesuai dengan hasil penelitian Shah GS, dkk ${ }^{8}$ tahun 2006 di Bangladesh, yang menunjukkan dari 100 anak yang positif infeksi dengue, didapati 52 anak (61,7\%) diantaranya mengalami trombositopenia pada penderita DBD dan SSD.

Pada infeksi dengue jumlah leukosit biasanya normal atau menurun dengan dominasi sel neutrofil. Terjadinya leukopenia pada infeksi dengue disebabkan karena adanya penekanan sumsum tulang akibat dari proses infeksi virus secara langsung ataupun karena mekanisme tidak langsung melalui produksi sitokin-sitokin proinflamasi yang menekan sumsum tulang. ${ }^{4}$

Data pada Tabel 4 menunjukkan bahwa dari 56 sampel penelitian terdapat 33 anak dengan jumlah leukosit normal, jumlah ini lebih banyak daripada jumlah anak dengan leukopenia. Hal ini mungkin dapat disebabkan karena jumlah sampel penelitian dengan derajat infeksi dengue yang lebih berat lebih banyak dibandingkan dengan derajat infeksi dengue ringan.

Hal yang serupa juga diungkapkan pada suatu penelitian di Thailand tahun 2008, bahwa berdasarkan hasil pemeriksaan leukosit saat awal dimasukkan ke rumah sakit didapatkan bahwa pasien dengan infeksi dengue ringan jika dibandingkan dengan pasien infeksi dengue berat, maka pasien dengan infeksi dengue berat memiliki jumlah leukosit lebih tinggi dibandingkan dengan pasien infeksi dengue ringan. $^{9}$

Pada saat demam, mulai terjadi pengurangan jumlah leukosit dan netrofil disertai limfositosis relatif. Leukopenia mencapai puncaknya sesaat sebelum demam turun dan normal kembali pada 2 3 hari setelah defervescence (demam turun). Penurunan trombosit umumnya mengikuti turunnya leukosit dan mencapai puncaknya bersamaan dengan turunnya demam. ${ }^{6}$

Hasil penelitian melalui uji korelasi Pearson mendapatkan nilai $\mathrm{p}=0,801$ dan koefisien korelasi $r=-0,034$ yang berarti bahwa korelasi tidak signifikan, dengan kekuatan korelasi lemah dan arah korelasi negatif. Dengan demikian, dapat ditarik kesimpulan bahwa tidak terdapat hubungan antara jumlah trombosit dan jumlah leukosit pada pasien anak dengan demam berdarah dengue di RSUP Prof. Dr. R.D. Kandou Manado.

Kelemahan dari penelitian ini mungkin bisa ditemukan bahwa peneliti tidak mengelompokkan kasus demam berdarah dengue sesuai dengan derajat keparahan penyakit sehingga hasilnya mungkin dapat terpengaruh.

\section{SIMPULAN}

Berdasarkan hasil penelitian dan pebahasan yang telah dijabarkan, maka dapat disimpulkan bahwa tidak terdapat hubungan yang signifikan antara jumlah trombosit dan leukosit pada pasien anak dengan demam berdarah dengue di RSUP Prof. Dr. Kandou Manado.

\section{DAFTAR PUSTAKA}

1. Achmadi UF. Demam Berdarah Dengue. Buletin Jendela Epidemiologi. 2010;2:1.

2. Kementerian Kesehatan RI. Profil Data Kesehatan Indonesia Tahun 2011. Jakarta: Kementerian Kesehatan RI;2012.

3. Hoffbrand A.V, Pettit J.E, Moss P.A.H. editors. Platelets, Blood Coagulation and Haemostasis. Dalam: Essential hematology. Edisi 5. New York: Blackwell Publishing; 2006. h.265-70. 
4. Rena N M, Utama S, Parwati T. Kelainan Hematologi pada Demam Berdarah Dengue. Jurnal Penyakit Dalam. 2009;10:218-23.

5. Guglani L, Kabra SK. T Cell Immunopathogenesis of Dengue Virus Infection. Dengue Bulletin 2005;29:5869.

6. Risniati Y, Tarigan L H, Tjitra E. Leukopenia Sebagai Prediktor Terjadinya Sindrom Syok Dengue Pada Anak Dengan Demam Berdarah Dengue di RSPI. Prof. dr. Sulianti Saroso. Media Litbang Kesehatan. 2011;21:96-100.
7. D. Sugianto, Samsi TK, Wulur H, A Sefanya, Dirgagunarsa, Jennings GB. Changes in Thrombocyte Count in Dengue Hemorrhagic Fever. 1993. [diakses: 17 Januari 2013]. Diunduh dari: http:/www.cerminduniakedokteran.com.

8. Shah GS, Islam S, Das BK. Clinical and Laboratory Profile of Dengue Infection in Children. Kathmandu University Med J. 2006;4:40-43.

9. Nanthakorn Eu-Ahsunthornwattana. Peripheral Blood Count for Dengue Severity Prediction : A prospective Study in Thai Children. Pediatrics. 2008;121:127. 